\title{
KAJIAN SIFAT MODULUS ELASTISITAS DAN KONSISTENSI TANAH LEMPUNG LUNAK PONTIANAK TERHADAP PENURUNAN ELASTIS AKIBAT ADANYA BEBAN STRUKTUR BANGUNAN DI PERMUKAAN
}

\author{
Dr. Ir. Marsudi, MT. \\ Dosen Jurusan Teknik Sipil, Fakultas Teknik, Universitas Tanjungpura
}

\begin{abstract}
ABSTRAK
Penyelidikan mengenai sifat modulus elastisitas (E) dan Konsistensi tanah lempung lunak memerlukan penyelidikan yang teliti, mengingat kondisi tanah lempung permukaan di wilayah Kota Pontianak mempunyai sifat keteknikan yang rumit dan beragam akibat kandungan material organik (tanah gambut) cukup tinggi. Perencanaan bangunan tinggi sangat memerlukan penyelidikan sifat-sifat tanah (soil properties) khususnya sifat modulus elastisitas tanah (E) dan konsistensi tanah yang berhubungan langsung dengan proses elastic settlement setelah struktur bangunan dikerjakan (dibangun).

Sifat modulus elastis dan konsistensi tanah lempung dapat dipakai sebagai acuan dasar untuk perencanaan bangunan wilayah kota, mengingat pesatnya perkembangan bangunan tinggi di Pontianak. Hasil luaran diharapkan berupa peta sebaran sifat modulus elastisitas dan konsistensi tanah akan dapat dipakai sebagai acuan/arahan dalam memperkirakan besarnya penurunan bangunan, sehingga dapat diantisipasi dengan perkuatan tanah untuk mengefisienkan biaya bagi pelaku pembangunan di dalam mendesain dan merencanakan bangunan tinggi tersebut.

Penelitian ini mempelajari sifat modulus elastisitas dan konsistensi lapisan lempung yang berada di permukaan tanah hingga kedalaman $6 \mathrm{~m}$, yang biasa dipakai sebagai penopang pondasi bangunan. Uji laboratorium mekanika tanah dengan Oedometer untuk konsolidasi, Triaxial Undrained Consolidation (CU) dan Unconfined Compressive Strength (UCS) bertujuan untuk mengetahui nilai elastisitas modulus tanah yang berhubungan dengan perhitungan settlement elastic akibat beban bangunan per satuan luas.
\end{abstract}

Kata Kunci :Modulus Elastisitas dan kosistensi tanah

\begin{abstract}
Research characteristic of soil Modulus Elasticity (E) and consistantion, has needed a detail research, meanwhile the surface layer on whole Pontianak areas has complicated properties and have many content of organic materials (peat land) it's too higher. The plan and design of high multy storied building to needed the detail of soil properties research as especially Modulus elasticity properties (E) and consistency, it could be influence of elastic settlement after the structures had erected.

Modulus elastic and consistenproperties of clay layer can apply such as for design of city building reference has so urged, considering the rapid grow up of high layer building in Pontianak. Hope the research output as like spread of modulus elasticity map could be using as references on predict how the elastic settlement will occurs, so that could be done to anticipate with stabilization of clay layers for efficiency cost to design and planning a high storied buildings.

In the research will be studied of modulus elasticity characteristic clay layer on sub surface reach to $6 \mathrm{~m}$, usually has support of foundation builds. Odometer test for consolidation, Triaxial Undrained Consolidation (CU) and Unconfined Compressive Strength (UCS) aim to knowing the modulus elasticity clay value had used for calculated base of elastic settlement had caused by the build load per units wide.
\end{abstract}

Keywords: Modulus of elasticity and consistency of soil 


\section{PENDAhULUAN}

\subsection{Latar Belakang}

Kota Pontianak sebagian besar menempati daerah hasil pengendapan delta Kapuas yang belum mengalami kompaksi, secara umum lapisan tanah permukaannya mempunyai sifat keteknikan yang kurang baik. Penyebaran lapisan lempung organik lunak, lanau dan gambut tidak dapat diprediksi secara fisual semata, tetapi memerlukan kajian yang detail untuk penyelidikan bawah permukaan yang ditunjang dengan pemboran inti.

Perencanaan pondasi suatu struktur bangunan secara umum memerlukan beberapa faktor seperti :

$>$ Beban yang akan diteruskan dari struktur bangunan ke dalam tanah,

$>$ Syarat-syarat peraturan pembangunan gedung dari daerah setempat,

$>$ Perilaku dan hubungan teganganregangan tanah sebagai akibat adanya beban di permukaan tanah,

\subsection{Perumusan Permasalahan}

Perumusan masalah dalam penelitian ini akan difokuskan pada sifat modullus elatisitas tanah lempung yang berhubungan dengan sifat penurunan elastis (elastic settlement) lapisan tanah akibat beban bangunan di wilayah kota, meliputi :

$\checkmark$ Susunan lapisan tanah (stratification of soil beds) daerah perkotaan.

$\checkmark$ Sifat-sifat fisik-mekanik tanah (soil properties), mulai dari kedalaman $0-6$ $\mathrm{m}$.

$\checkmark \quad$ Penyebaran lapisan tanah lanau, lempung lunak dan lapisan gambut.

$\checkmark$ Penyebaran dan pola settlement tanah terhadap tekanan dari permukaan.

Pemecahan permasalahan yang tercantum di atas yaitu dengan melakukan penelitian menyeluruh mengenai sifat fisik-mekanik dan komposisi perlapisan endapan lapisan lempung.

\subsection{Maksud dan Tujuan}

$\checkmark$ Mengidentifikasi kondisi penyebaran lapisan tanah lempung di wilayah Kota Pontianak.

$\checkmark \quad$ Mengetahui sifat elastis modulus tanah lempung untuk perhitungan settlement segera.

marsudidr@yahoo.co.id

\section{STUDI PUSTAKA \\ 2.1. Tanah Lempung}

Tanah lempung didefinisikan sebagai bahan kohesif, yaitu suatu bahan yang partikelpartikelnya cenderung berlekatan akibat gabungan tarikan partikel dan pengaruh air, dapat pula dikatakan lempung merupakan kumpulan partikel mineral yang mempunyai indeks plastisitas sesuai dengan batas Atterberg yang pada waktu mengering membentuk suatu massa yang bersatu sedemikian rupa sehingga diperlukan gaya untuk memisahkan setiap butiran mikroskopisnya.

\subsection{Penurunan Tanah}

Besarnya penurunan di permukaan tanah akibat kompresibilitas tanah lempung, lanau dan pasir diakibatkan oleh kompresi udara dan air di dalam rongga pori (void), deformasi butiran partikel lempung, lanau, pasir dan keluarnya air pori dari rongga pori.

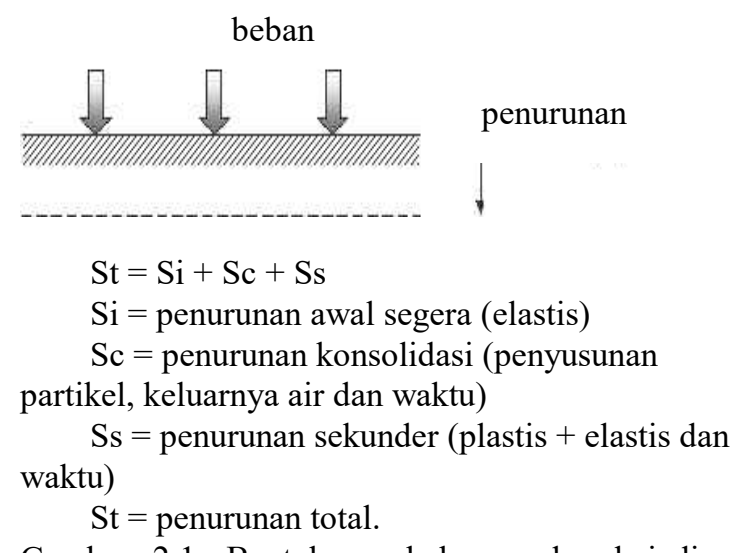

Gambar 2.1. Bentuk pembebanan dan kejadian penurunan pada permukaan tanah.

\subsection{Teori Elastis pada Tanah}

\subsubsection{Perilaku Elastisitas dan Plastisitas}

Hubungan antara regangan dan tegangan, di dalam material elastis deformasi (seperti contoh regangan) hasil dari pembebanan tegangan adalah fungsi dari tekanan dan secara penuh akibat sebaliknya. Jika hubungan antara regangan dan tegangan linier di atas kisaran tertentu, hukum Hooke's dapat digunakan pada kisaran itu. Hubungan tegangan - regangan untuk material elastik sempurna seperti ditunjukkan pada Gambar 2.2 (a). Tegangan adalah sebanding dengan regangan atau ambil arah yang lain berlawanan terhadap penambahan deformasi sebanding terhadap deformasi. Sifat elastik - plastis ( dapat dipakai untuk contoh logam) yang diwakili garis putus-putus pada gambar 2.2 (b). 


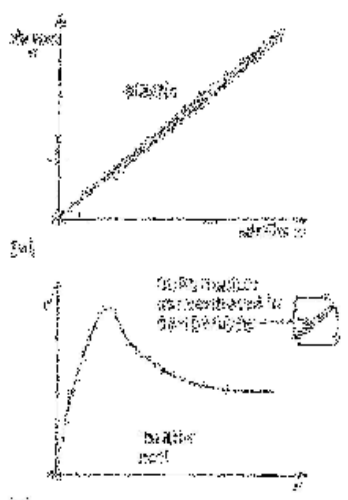

(n):

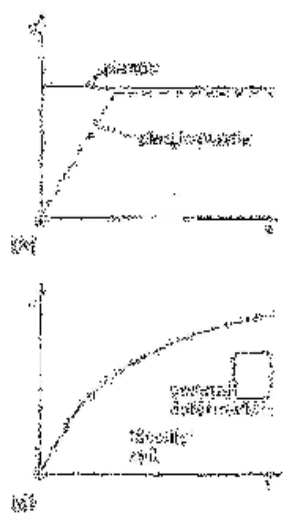

Gambar 2.2. Hubungan tegangan \& regangan untuk (a) material elastis sempurna, (b) material plastis dan elastis-plastis, (c) tipe tanah yang rapuh (brittle), (d) tipe tanah liat (ductile).
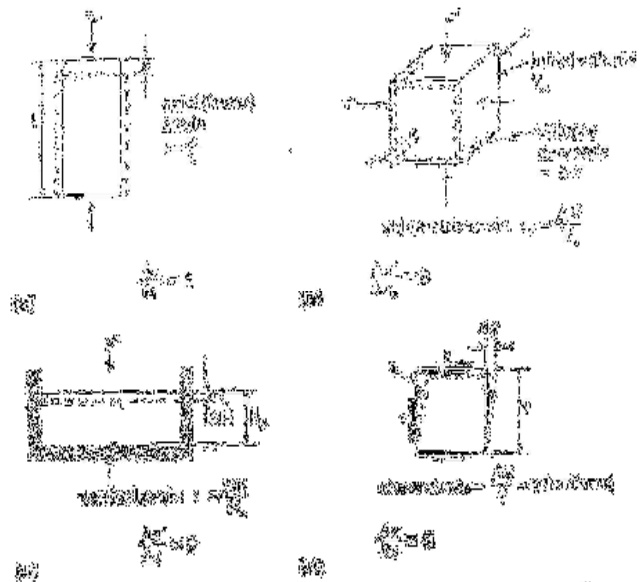

in

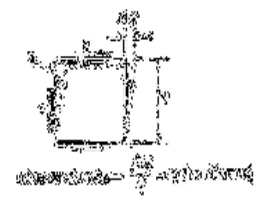

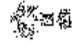

Gambar 2.3. Parameter elastis modulus (a)

Young's modulus (E), (b) bulk modulus (B), constrain modulus (D), (d) shear modulus (G).

Parameter elastis tanah adalah perkiraan gambaran linier pada kisaran tegangan yang terbatas. Pada lapisan tanah parameter yang ada sangat bervariasi menurut kondisi seperti level tegangan, sejarah tegangan sebelumnya, kedalaman dan jenisnya. Beberapa parameter secara praktis sulit didapatkan di dalam percobaan untuk mengukur sifat-sifat tanah di laboratorium.

\subsubsection{Parameter-parameter Elastis}

Berikut parameter elastis atau "moduli", digunakan untuk analisa tegangan dan kondisi regangan yang dapat diringkas sebagai berikut (Lambe dan Whitman (1979) :
a. Young modulus
b. Bulk modulus
c. Constrained modulus (D)
d. Shear modulus
e. Poisson's ratio

Modulus adalah secara numerik nilai tegangannya tinggi dan biasanya ditunjukkan dalam meganewton per $\mathrm{m}^{2}\left(\mathrm{MN} / \mathrm{m}^{2}\right)$ juga disebut megapascal (Mpa),

kecuali Poisson's ratio yang tak berdemensi. Pengaruh pada tipe mengenai beban di atas pada contoh material elastis yang diidealkan
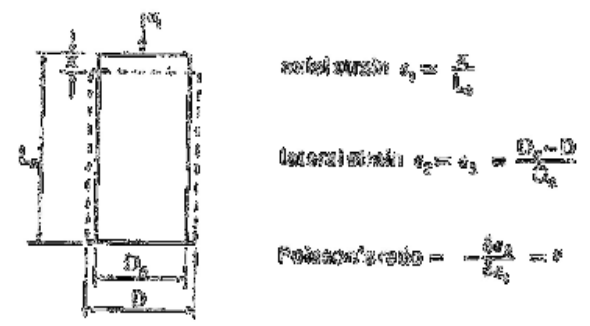

Gambar 2.4 Kondisi yang mewakili angka Poisson's ratio

1) Tekanan Uniaxial

Tegangan (stress) vertikal $\left(\sigma_{\mathrm{v}}\right)$ menghasilkan regangan (strain) vertikal $(\varepsilon$. $)=\mathrm{x} / \mathrm{L}(\mathrm{Gb} 2.3 \mathrm{a})$

Pada kisaran elastis, perubahan regangan dihubungkan terhadap perubahan tegangan dengan persamaan :

$$
\delta \sigma_{\mathrm{v}}=\mathrm{E} . \delta \varepsilon
$$

Dimana E didefinisikan sebagai Young's modulus elastis

$$
\mathrm{E}=\frac{\delta \sigma_{v}}{\delta \varepsilon}
$$

Untuk kondisi tanpa pengeringan (undrained)

$$
\mathrm{E}=\frac{\delta \sigma_{v}}{\delta \varepsilon}
$$

dan untuk kondisi pengeringan (drained)

$\mathrm{E}=\frac{\delta \sigma^{\prime} v}{\delta \varepsilon}$

jika tegangan diukur dalam $\mathrm{kPa}$, dan regangan ditunjukkan dalam persen, maka

$\mathrm{E}=\frac{\delta \sigma_{v}}{\delta \varepsilon \%} \times \frac{1}{10} \mathrm{MN} / \mathrm{m}^{2}$ (atau Mpa)..

b). Konsolidasi isotropis.

Setara semua skitar tegangan efektif digunakan untuk contoh yang menghasilkan perubahan dalam volume $(\mathrm{V})$, regangan volumetrik $\left.\left(\varepsilon_{\mathrm{v}}\right)=\Delta \mathrm{V} / \mathrm{V}_{0}\right)$ (Gb 2.3b). Bulk modulus pengeringan (drained), didefinisikan sebagai :

$\mathrm{B}=\frac{\delta \sigma^{\prime}{ }_{v}}{\Delta \varepsilon_{v}}$

Dan dihubungkan terhadap $\mathrm{E}^{\prime}$ dan $\mathrm{v}^{\prime}$ dengan persamaan

$\mathrm{B}=\frac{E^{\prime}}{3\left(1-2 v^{\prime}\right)}$

Koefisien pemampatan volume $\left(\mathrm{m}_{\mathrm{vi}}\right)$ diperoleh dari tahapan uji konsolidasi triaxial isotropis, dihubungkan terhadap B dengan persamaan : 


$$
\mathrm{B}=\frac{1}{m_{\cdot v i}}
$$

c).Pemampatan tertekan (confined compression)

Tegangan vertikal digunakan pada contoh bentuk potongan (seperti pada uji konsolidasi satu dimensi) (gb 2.3c), menghasilkan perubahan pada arah axial hanya memberikan regangan axial

$$
\varepsilon=\frac{\Delta H}{H_{0}} .
$$

Modulus constrain (D), didefinisikan sebagai

$\mathrm{D}=\frac{\Delta \sigma^{\prime}}{\Delta \varepsilon}$

Dan dihubungkan terhadap E' dan v' dengan persamaan

$$
\mathrm{D}=\frac{E^{\prime}\left(1-v^{\prime}\right)}{\left(1+v^{\prime}\right)\left(1-2 v^{\prime}\right)}
$$

Koefisien pemampatan volume $\left(\mathrm{m}_{\mathrm{v}}\right)$ didapatkan dari tahapan uji konsolidasi satu dimensi yang dihubungkan terhadap D dengan persamaan

$$
\mathrm{D}=\frac{1}{m_{v}}
$$

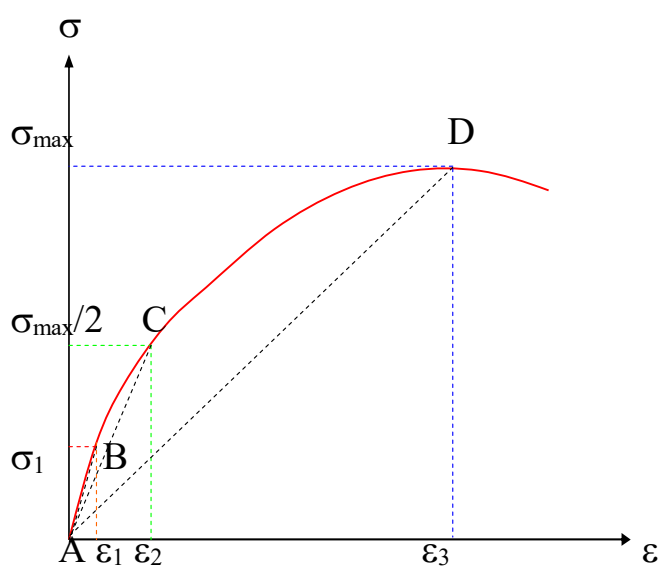

Gambar 2.5 Distribusi Young's modulus dari hubungan tegangan nonlinier- regangan (A) mod. tangent, (B) initial tangent mod., (C) secant mod. (D) correct to point of origin.

\subsection{Penurunan SegeraTanah homogen dengan tebal tak terhingga.}

Persamaan penurunan segera atau penurunan elastis dari pondasi yang terletak di permukaan tanah yang homogen, elastis, isotrofis pada media semi tak terhingga, dinyatakan oleh :

$$
\mathrm{S}_{\mathrm{i}}=\frac{q B}{E}\left(1-\mu^{2}\right) \mathrm{I}_{\mathrm{p}}
$$

Dimana :

$\mathrm{S}_{\mathrm{i}}=$ penurunan segera.

$\mathrm{q}=$ tambahan tegangan

$\mathrm{E}=$ modulus elastisitas

$\mathrm{B}=$ lebar pondasi

$\mu=$ angka poisson

$\mathrm{I}_{\mathrm{p}}=$ faktor pengaruh

Untuk nilai perkiraan angka Poisson dan nilai modulus elastisitas dapat dilihat pada table angka Poisson $(\mu)$ ( Bowles, 1968).

Nilai faktor pengaruh tergantung pada lokasi titik yang ditinjau, bentuk dan kekakuan pondasi di mana penurunan akan dihitung. Untuk pondasi fleksibel Terzaghi (1943) menyarankan nialai $I_{p}$ untuk menghitung penurunan pada sudut luasan empat persegi panjang adalah sebagai berikut :

$$
\begin{aligned}
& \mathrm{I}_{\mathrm{p}}=\frac{1}{\pi}\left(\frac{L}{B} \ln \left\langle\frac{1+\sqrt{\left(L / B^{2}+1\right)}}{\frac{L}{B}}\right\rangle+\ln \right. \\
& \left.\left\langle\frac{L}{B}+\sqrt{ }\left(\frac{L}{B^{2}}\right)+1\right\rangle\right) \ldots \ldots(2.10)
\end{aligned}
$$

dengan $\mathrm{L}$ dan $\mathrm{B}$ adalah panjang dan lebar pondasi. Nilai $I_{p}$ untuk berbagai tipe pondasi dapat dilihat pada table di bawah ini : 
Tabel 2.5 Faktor-faktor pengaruh $\mathrm{I}_{\mathrm{m}}$ (Lee, 1962) dan $\mathrm{I}_{\mathrm{p}}$ (Schleicher) untuk pondasi

kaku, dan factor pengaruh untuk fondasi fleksibel (Terzaghi, 1943) (dari Bowles, 1968).

\begin{tabular}{|c|c|c|c|c|c|}
\hline \multirow[t]{2}{*}{ Bentuk } & \multicolumn{3}{|c|}{ Fleksibel $\left(\mathrm{I}_{\mathrm{p}}\right)$} & \multicolumn{2}{|c|}{ Kaku } \\
\hline & Pusat & Sudut & Rata-rata & $\mathrm{I}_{\mathrm{p}}$ & $\mathrm{I}_{\mathrm{m}}$ \\
\hline Lingkaran & 1.00 & 0.64 & 0.85 & 0.88 & \\
\hline Bujur sangkar & 1.12 & 0.36 & 0.95 & 0.82 & 3.70 \\
\hline Empat persegi panjang & & & & & \\
\hline $\mathrm{L} / \mathrm{B}=1.5$ & 1.36 & 0.68 & 1.20 & 1.06 & 4.12 \\
\hline$=2.0$ & 1.53 & 0.77 & 1.31 & 1.2 & 4.38 \\
\hline$=5.0$ & 2.10 & 1.05 & 1.83 & 1.70 & 4.82 \\
\hline$=10.0$ & 2.52 & 1.26 & 2.25 & 2.10 & 4.93 \\
\hline$=100.0$ & 3.38 & 1.69 & 2.96 & 3.40 & 5.06 \\
\hline
\end{tabular}

Sumber : Buku Teknik Pondasi 1, Gramedia Pustaka Utama, 1996.

\section{METODE PENELITIAN}

\subsection{Metodologi}

Metode penyelidikan yang dilakukan adalah survei lapangan baik di atas maupun di bawah permukaan dengan sistem membagi daerah berdasar administrasi Kecamatan, kemudian setiap kecamatan dilakukan pemboran 5 lokasi yaitu kedalaman 6,45 m (di tepi 4 lokasi dan 1 lokasi di tengah). Sampel diuji di laboratorium Mekanika Tanah mengguna-kan Uji Triaxial untuk memperoleh nilai Modulus Elastisitas tanah lempung.

\subsection{Diskripsi sampel tanah dan Korelasi}

\subsubsection{Diskripsi hasil contoh tanah}

Pengamatan visual dan diskripsi hasil pemboran dilakukan langsung di lapangan

dengan mengamati warna, besar ukuran butir, kekerasan, kandungan air, plastisitas dan organik. Berikut di bawah ini, tabel hasil diskripsi tiap sampel berdasar kedalaman :

Tabel :3.1 Diskripsi sampel tanah

\begin{tabular}{|l|l|c|l|}
\hline No & $\begin{array}{l}\text { Lokasi } \\
\text { pengambilan } \\
\text { sampel }\end{array}$ & Kedalaman & \multicolumn{1}{|c|}{$\begin{array}{l}\text { Diskripsi lapisan } \\
\text { tanah }\end{array}$} \\
\hline 1 & $\begin{array}{l}\text { Pontianak } \\
\text { Selatan }\end{array}$ & $0,45-2,45$ & $\begin{array}{l}\text { Lempung; } \\
\text { berwarna abu-abu, } \\
\text { sangat lunak, ada } \\
\text { organik, agak } \\
\text { plastis, kandungan } \\
\text { air besar. } \\
\text { Lempung; } \\
\text { berwarna abu-abu } \\
\text { gelap, sangat } \\
\text { lunak, plastis } \\
\text { tinggi, kandungan } \\
\text { air tinggi. } \\
\text { Lempung lanauan; } \\
\text { abu-abu cerah, }\end{array}$ \\
& $2,46-4,45$ \\
& $4,46-6,45$ & &
\end{tabular}

\begin{tabular}{|c|c|c|c|}
\hline & & & $\begin{array}{lr}\text { lunak, } & \text { agak } \\
\text { plastisitas } & \text { tinggi, } \\
\text { kandungan } & \text { air } \\
\text { tinggi } & \end{array}$ \\
\hline 2 & $\begin{array}{l}\text { Pontianak } \\
\text { Kota }\end{array}$ & $2,46-4,45$ & $\begin{array}{l}\text { Lempung; } \\
\text { berwarna abu-abu } \\
\text { cerah,sangat } \\
\text { lunak, organik dan } \\
\text { akar, lembek, } \\
\text { kandungan air } \\
\text { tinggi. } \\
\text { Lempung; } \\
\text { berwarna abu-abu } \\
\text { gelap, lunak, } \\
\text { plastis tinggi, } \\
\text { kandungan air } \\
\text { tinggi. } \\
\text { Lempung lanauan; } \\
\text { abu-abu cerah, } \\
\text { lunak, } \\
\text { plastis, kandungan } \\
\text { air sedang. }\end{array}$ \\
\hline 3 & $\begin{array}{l}\text { Pontianak } \\
\text { Barat }\end{array}$ & $2,46-4,45$ & $\begin{array}{l}\text { Lempung; } \\
\text { berwarna abu-abu, } \\
\text { sangat lunak, ada } \\
\text { organik, agak } \\
\text { plastis, } \\
\text { kerang, kandungan } \\
\text { air besar. } \\
\text { Lempung; } \\
\text { berwarna abu-abu } \\
\text { gelap, rangat } \\
\text { lunak - lunak, } \\
\text { plastis tinggi, } \\
\text { kandungan air } \\
\text { tinggi. } \\
\text { Lempung lanauan; } \\
\text { abu-abu cerah, } \\
\text { lunak, agak } \\
\text { plastis, kandungan } \\
\text { air sedang. }\end{array}$ \\
\hline 4 & $\begin{array}{l}\text { Pontianak } \\
\text { Utara }\end{array}$ & $2,46-4,45$ & $\begin{array}{l}\text { Lempung; } \\
\text { berwarna abu-abu, } \\
\text { lunak, ada } \\
\text { organik, agak } \\
\text { plastis, kandungan } \\
\text { air tinggi. } \\
\text { Lempung; } \\
\text { berwarna abu-abu } \\
\text { gelap, lunak, } \\
\text { plastis, kandungan } \\
\text { air tinggi. } \\
\text { Lempung lanauan; } \\
\text { abu-abu coklat, } \\
\text { lunak, agak } \\
\text { plastis, kandungan } \\
\text { air sedang. }\end{array}$ \\
\hline 5 & $\begin{array}{l}\text { Pontianak } \\
\text { Timur }\end{array}$ & $0,45-2,45$ & $\begin{array}{l}\text { Lempung; } \\
\text { berwarna abu-abu, } \\
\text { lunak, organik dan } \\
\text { akar, ada kerang, } \\
\text { agak plastis, } \\
\text { lembek. }\end{array}$ \\
\hline
\end{tabular}




\begin{tabular}{|l|l|l|}
\hline & $2,46-4,45$ & $\begin{array}{l}\text { Lempung; } \\
\text { berwarna abu-abu } \\
\text { gelap, lunak, } \\
\text { plastis tinggi, } \\
\text { kandungan air } \\
\text { tinggi. } \\
\text { Lempung lanauan; } \\
\text { abu-abu coklat, } \\
\text { lunak, plastis } \\
\text { sedang, air } \\
\text { kandungan air a } \\
\text { tinggi. }\end{array}$ \\
\hline
\end{tabular}

Pontianak Kota, Pontianak Utara, Pontianak Timur dan Pontianak Selatan (Gambar 3.1).

\section{PENGOLAHAN DATA DAN ANALISA}

\subsection{Hasil Penelitiann}

Perhitungan data hasil pengujian meliputi pengujian Laboratorium untuk mendapatkan nilai Modulus Elastisitas (E). Pengujian Laboratorium mengunakan satu set alat Unconfined Compression
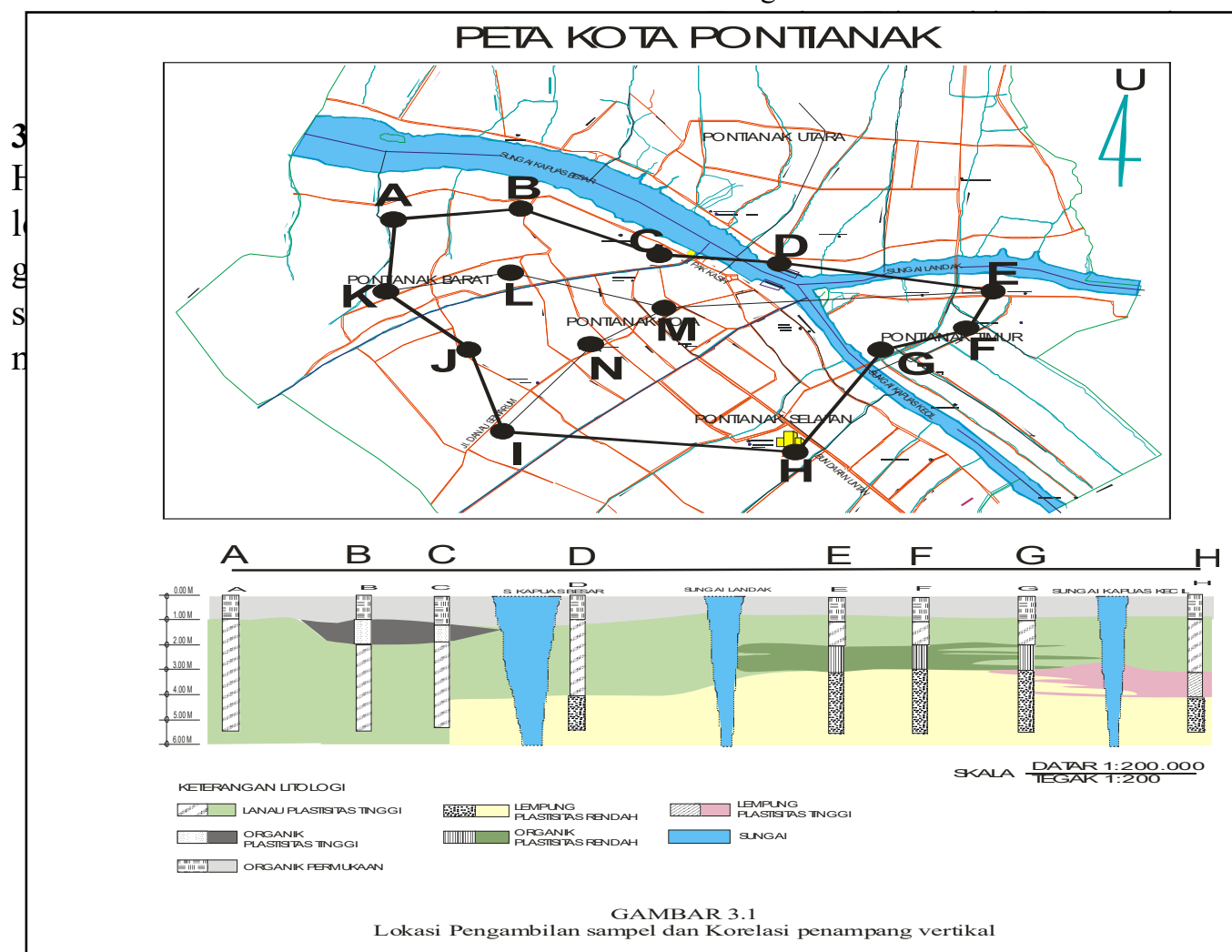

Gambar 3.1. Korelasi penampang vertical lapisan tanah di Pontianak Tanpa skala

Tabel 4.1. Nilai modulus elastisitas tanah lempung menggunakan UCS

\begin{tabular}{|c|c|c|}
\hline \multirow{3}{*}{$\begin{array}{c}\text { No.Sampel } \\
\text { tanah Lempung }\end{array}$} & \multicolumn{2}{|c|}{ Tanah Lempung } \\
\hline & Modulus Elastisitas $\left(\mathrm{Kg} / \mathrm{Cm}^{2}\right)$ & \multirow{2}{*}{$\begin{array}{c}\text { Rata-rata } \\
\left(\mathrm{Kg} / \mathrm{cm}^{2}\right)\end{array}$} \\
\hline & E $50 \%$ & \\
\hline Ala & 1,4132 & \multirow{2}{*}{2,3540} \\
\hline Alb & 2,6380 & \\
\hline $\mathrm{B} 2 \mathrm{a}$ & 1,9910 & \multirow{2}{*}{1,814} \\
\hline $\mathrm{B} 2 \mathrm{~b}$ & 1,0897 & \\
\hline $\mathrm{C} 3 \mathrm{a}$ & 1,5302 & \multirow{2}{*}{1,730} \\
\hline $\mathrm{C} 3 \mathrm{~b}$ & 1,4524 & \\
\hline D4a1 & 1,9292 & \multirow{2}{*}{2,516} \\
\hline $\mathrm{D} 4 \mathrm{a} 2$ & 2,4367 & \\
\hline E5a1 & 1,6557 & 2,186 \\
\hline
\end{tabular}




\begin{tabular}{|c|c|c|}
\hline $\mathrm{E} 5 \mathrm{~b} 2$ & 2,3385 & \multirow{3}{*}{1,646} \\
\hline F6a1 & 1,4564 & \\
\hline F6b2 & 1,3416 & \\
\hline
\end{tabular}

Tabel 4.2 Nilai Modulus Elastisitas tanah lempung menggunakan CU

\begin{tabular}{|c|c|c|c|c|}
\hline $\begin{array}{c}\text { No. Sampel } \\
\text { tanah lempung }\end{array}$ & & $\begin{array}{c}\text { Tegangan }(\sigma) \\
\left(\mathrm{Kg} / \mathrm{cm}^{2}\right)\end{array}$ & Regangan $(\varepsilon)$ & $\begin{array}{c}\text { Modulus Elastisitas (E) } \\
\left(\mathrm{Kg} / \mathrm{cm}^{2}\right)\end{array}$ \\
\hline \multirow{3}{*}{$\begin{array}{l}\text { A. Jln. Karet } \\
\text { Pontianak Barat }\end{array}$} & 2 & 0,1754 & 0,0545 & 3,2185 \\
\hline & 4 & 0,2368 & 0,0519 & 4,5614 \\
\hline & 6 & 0,3198 & 0,0883 & 4,6238 \\
\hline \multirow{3}{*}{$\begin{array}{l}\text { B. } \text { Jeruju } \\
\text { Pontianak Barat }\end{array}$} & 2 & 0,2168 & 0,0720 & 3,0141 \\
\hline & 4 & 0,2713 & 0,0786 & 3,4526 \\
\hline & 6 & 0,3198 & 0,0883 & 3,6238 \\
\hline \multirow{3}{*}{$\begin{array}{l}\text { C. Pelabuhan } \\
\text { Pontianak Barat }\end{array}$} & 2 & 0,1534 & 0,0569 & 2,6963 \\
\hline & 4 & 0,1669 & 0,0515 & 3,2417 \\
\hline & 6 & 0,3097 & 0,0794 & 3,9005 \\
\hline \multirow{3}{*}{$\begin{array}{c}\text { D. J1. Bardan, Siantan } \\
\text { Pontianak Utara }\end{array}$} & 2 & 0,1669 & 0,0576 & 2,8373 \\
\hline & 4 & 0,2157 & 0,0635 & 3,3989 \\
\hline & 6 & 0,3153 & 0,0875 & 3,6034 \\
\hline \multirow{3}{*}{$\begin{array}{l}\text { E. Kantor Lurah } \\
\text { Pontianak Timur }\end{array}$} & 2 & 0,1926 & 0,0715 & 2,6937 \\
\hline & 4 & 0,2449 & 0,0835 & 2,9348 \\
\hline & 6 & 0,3011 & 0,0901 & 3,3433 \\
\hline \multirow{3}{*}{$\begin{array}{l}\text { F. R. Sakit Yarsi } \\
\text { Pontianak Timur }\end{array}$} & 2 & 0,2077 & 0,0663 & 3,1329 \\
\hline & 4 & 0,2553 & 0,0667 & 3,8254 \\
\hline & 6 & 0,3097 & 0,0796 & 3,8931 \\
\hline \multirow{3}{*}{$\begin{array}{l}\text { G. Kp. Bugis } \\
\text { Pontianak Timur }\end{array}$} & 2 & 0,1566 & 0,0573 & 2,7329 \\
\hline & 4 & 0,1737 & 0,0634 & 2,7402 \\
\hline & 6 & 0,2357 & 0,0814 & 2,8956 \\
\hline \multirow{3}{*}{$\begin{array}{l}\text { H. Blk Mega Mall } \\
\text { Pontianak Selatan }\end{array}$} & 2 & 0,1995 & 0,0678 & 2,9424 \\
\hline & 4 & 0,2515 & 0,0751 & 3,3489 \\
\hline & 6 & 0,3209 & 0,0898 & 3,5726 \\
\hline \multirow{3}{*}{$\begin{array}{l}\text { I. Pro X1 D.Sentarum } \\
\text { Pontianak Tengah }\end{array}$} & 2 & 0,1518 & 0,0570 & 2,6637 \\
\hline & 4 & 0,1697 & 0,0602 & 2,8171 \\
\hline & 6 & 0,2611 & 0,0751 & 3,4766 \\
\hline \multirow{3}{*}{$\begin{array}{l}\text { J. Komp. Arikarya } \\
\text { Pontianak Barat }\end{array}$} & 2 & 0,1909 & 0,0688 & 2,7746 \\
\hline & 4 & 0,2563 & 0,0724 & 3,5413 \\
\hline & 6 & 0,3092 & 0,0821 & 3,7656 \\
\hline \multirow{3}{*}{\multicolumn{2}{|c|}{$\begin{array}{ll}\text { K. Pal. Lima } & 2 \\
\text { Pontianak Barat } & 4 \\
& 6\end{array}$}} & 0.17373 & 0.0634 & 2,7406 \\
\hline & & 0.25531 & 0.0667 & 3,8134 \\
\hline & & 0,3294 & 0,0826 & 3,9878 \\
\hline
\end{tabular}




\subsection{Grafik Penurunan Elastis}

Secara grafis dapat digambarkan besaran penurunan elastis pada jenis tiang bulat dan bujursangkar, pada tanah lempung yang diambil pada kedalaman $2 \mathrm{~m}$, $4 \mathrm{~m}$ dan $6 \mathrm{~m}$.

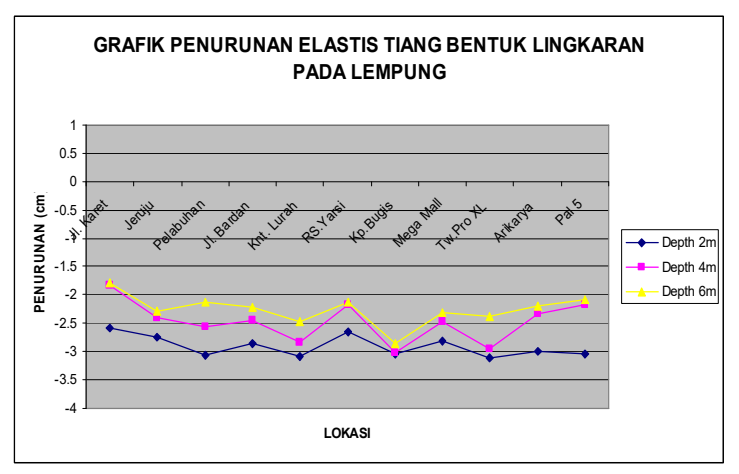

Gambar 4.1 Grafik penurunan elastis tiang bentuk bulat pada tanah lempung

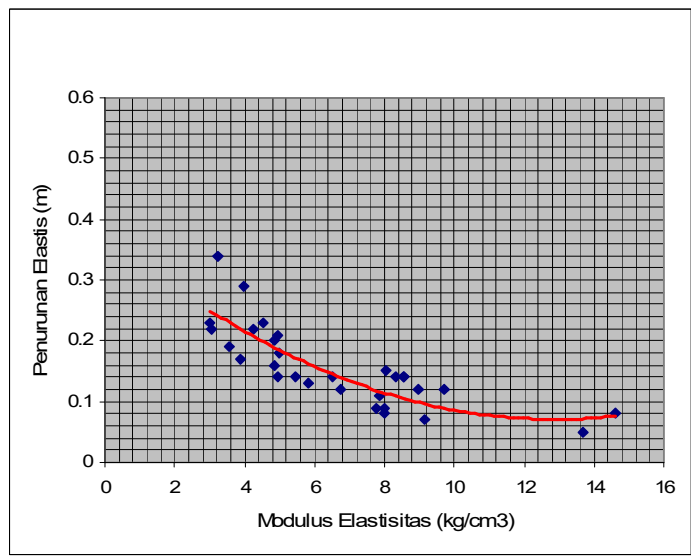

Gambar 4.3 Nilai E dari Modulus Tangen Terhadap Penurunan Elastis

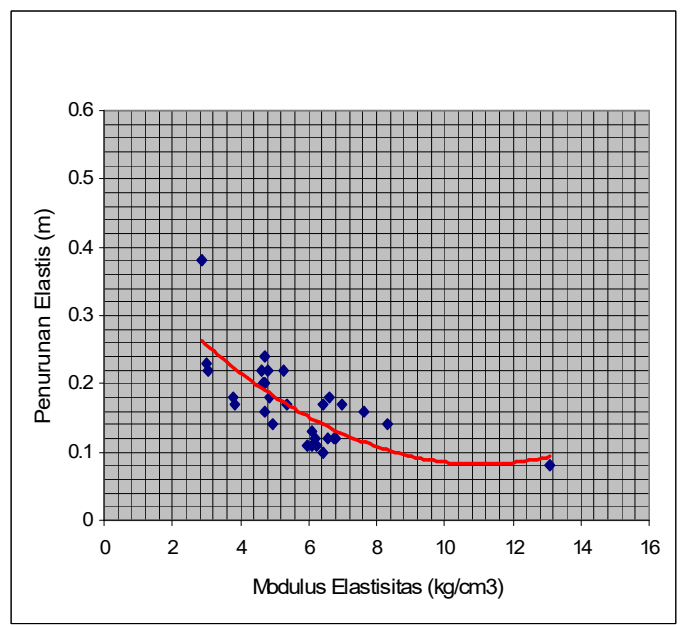

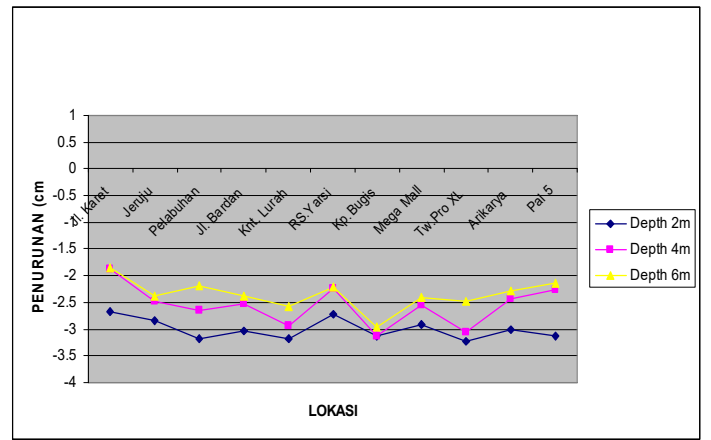

Gambar 4.2 Grafik penurunan elastis tiang bentuk bujur sangkar pada tanah lempung

\section{Grafik hubungan antara nilai Modulus Elastisiras (E) dan Penurunan Elastis}

Gambar 4.4 Nilai E dari Modulus Secant rata-rata Terhadap Penurunan Elastis

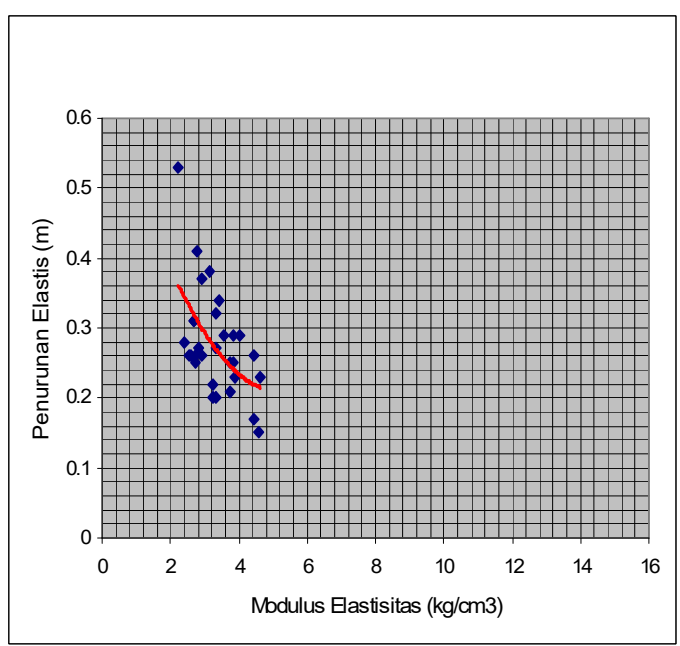

Gambar 4.5 Nilai E dari Modulus Secant maksimum Terhadap Penurunan Elastis. 


\section{PENUTUP}

\subsection{Kesimpulan}

Berdasarkan hasil penelitian dan analisa serta perhitungan dapat disimpulkan sebagai berikut:

1) Semakin bertambah kedalaman, tingkat kepadatan tanah lempung lunak Pontianak semakin tinggi. Hal ini dapat dilihat dari nilai kadar air (w) mengecil, berat volume $(\gamma)$ bertambah, dan angka pori (e) tanah mengecil.

2) Daerah penelitian umumnya didominasi oleh tanah lempung lunak plastisitas tinggi, jenis mineral tanah lunak Pontianak berada pada tingkatan normal sampai aktif. Banyaknya mineral organik yang tersebar pada permukaan akibat pengaruh dari sebaran lapisan gambut di beberapa tempat.

3) Daerah Pontianak Barat, Pontianak Utara dan Pontianak Timur memiliki karakteristik sifat fisik dengan nilai yang cenderung lebih tinggi dibanding wilayah lainnya, terutama daerah pinggiran. Hal ini disebabkan oleh kandungan lempung lanauan yang lebih banyak dalam tanah lempungnya. Tanah lempung organik plastisitas tinggi dan rendah hanya mewakili satu meter kedalaman saja hingga dapat dianggap sebagai sisipan.Nilai E lebih besar sehingga bila ada beban struktur bangunan nilai penurunan elastisnya lebih kecil.

4) Lokasi Jl. Karet Pontianak Barat dan Pontianak Utara mengalami penuru-nan elastis yang lebih kecil dibandingkan ketiga wilayah Keca-matan lainnya (Kecamatan Pontianak Selatan, Timur dan Tengah), hal ini dikarenakan nilai modulus elastisitasnya lebih besar. Dengan melihat penurunan elastis tanah akibat adanya beban menunjukkan daerah Kecamatan Pontianak Tengah (Kota) Pontianak Selatan dan Timur menunjukkan angka yang besar, karena nilai modulus tanah lempungnya kecil.

5) Semakin bertambah kedalaman semakin kecil penurunan elastis yang terjadi. Hal ini dikarenakan nilai modulus elastisitas yang bertambah besar karena kandungan lanau semakin meningkat. Demikian juga sangat dipengaruhi oleh berat volume tanah, kuat geser dan sudut geser yang semakin meningkat.

\subsection{Saran.}

Berdasarkan pengamatan dan pengalaman yang diperoleh selama melakukan penelitian, maka penulis menyarankan :

1) Melakukan pengembangan untuk penelitian selanjutnya dengan cara menambah jumlah titik pengambilan sampel dan kedalaman titik pengamatan sehingga hasil yang diperoleh akan lebih baik dan akurat.

2) Melakukan penelitian karakteristik sifat fisis dan mekanis tanah lempung lunak dengan metode penelitian yang sama sehingga dapat dibandingkan hasilnya untuk daerah lain selain Kota Pontianak.

\section{DAFTAR PUSTAKA}

Braja M.Das, 1994,'Principles of Geotechnical Engineering" $3^{\text {th }}$ edition, PWS Co Publishing, Boston, Massachusetts, USA.

$>$ E.J. Garboczi, Christoph H, W. Val Pinezewski, 2002, Computation of Linier elastic Properties from Microtomographic images, Journal of Geophysics, Vol 67, No.5, NIST, USA.

$>$ Djuhudijat, Tjetje Apandi, "Laporan Penyelidikan Geologi Tata lingkungan Wilayah Kota Madya Pontianak dan Sekitarnya, DGTL Bandung, 1982.

$>\quad$ Failmezger R., Rom D., Ziegler S.B.(1999) "Behavioral Characteristics of Residual Soils. 5 case-histories comparing settlement predictions by SPT and DMT" ASCE Geot. Special Pub. No. 92, Edelen, ASCE, Reston, Virginia:

Gero Marzahn, 1999, "Investigation on Initial Settlement of Dry-Stacked Masonry under Compression", in Lacer No.4, Universitat Leipzig.

Jean Louis Briaud, 2003, "Introduction to Soil Moduli", Academic Course, Dept of Civil Engineering, Texas,USA.

Hary Christady, H. , 1992, Mekanika Tanah I, Gramedia Pustaka Utama, Jakarta.

$>\quad$ K.H. Head, 1986,'Manual of Soil Laboratoy Testing" Volume 3, ELE Int Limited, Pentech Press, London

Lambe T.W \& Whitman R.V, 1979, third Ed, "Soil Mechanics" John Willey \& Sons, Inc, New York, USA. 
$>$ Mayne P. 2001, "Settlements predicted by SPT and DMT vs settlement measured of a 13-story Dormitory Building for Georgia State Univ. Atlanta".

$>$ P.A. Vermeer \& H.P. Neher, 2000, ”A Soft soil Model that Accounts for Creep", Journal
Computational Geotechnics, 10 years of Plaxis Int, Stuttgart, Germany. . 